\title{
Perang Balkan dan Implikasinya terhadap Kehidupan Sosial-Politik Islam di Eropa Tenggara (1876-1914 M)
}

\author{
Pebi Sapitri \\ Fakultas Adab dan Humaniora \\ Universitas Islam Negeri Raden Fatah Palembang \\ E-mail: pebisafitri_uin@radenfatah.ac.id
}

\begin{abstract}
Abstrak
Penelitian ini mendeskripsikan rangkaian sejarah terjadinya Perang Balkan dan implikasi yang ditimbulkannya bagi kehidupan muslim di sana. Penelitian ini mengambil tiga permasalahan pokok yaitu (1) sebab terjadinya Perang Balkan, (2) kronologi perang Balkan, dan (3) Bagaimana implikasi perang Balkan terhadap kehidupan sosial-politik Islam di Eropa Tenggara.Metode penelitian yang digunakan dalam skripsi ini adalah metode penelitian sejarah.Dalam metode penelitian sejarah ada 4 tahapan yaitu (1) Heuristik, (2) Kritik Sumber/ Verifikasi, (3) Interpretasi dan (4) Historiografi.Pendekatan yang digunakan dalam penelitian ini ada dua yaitu pendekatan politik dan sosiologi.Sementara teori yang penulis gunakan dalam penelitian ini ialah teori konflik dan teori perubahan sosial. Hasil penelitian yang penulis dapatkan ialah: secara kronologis perang Balkan diawali dengan permasalahan mengenai Macedonia yang pada akhirnya dijadikan alasan untuk melegitimasikan perang. Pada dasarnya, penyebab utama terjadinya perang Balkan ini ialah karena ambisi dan dendam pribadi antara masing-masing penguasa negeri Balkan dengan Kesultanan Turki Utsmani. Didorong pula oleh kemunduran kesultanan, dominasi Rusia, perang Turki-Itali (1911-1912), ide nasionalisme, propaganda, terbentuknya aliansi Balkan dan gagalnya diplomasi. Pecahnya perang Balkan bukan hanya mengakibatkan perubahan geo-politik akan tetapi juga merupakan malapetaka kemanusiaan bagi Muslim di Balkan yang saat itu harus menerima kenyataan bahwa keadaan mereka tidak lagi sama seperti ketika dipimpin oleh Muslim sebab otoritas telah beralih kepada non-Muslim.
\end{abstract}

Kata Kunci: Perang Balkan, Implikasi Sosial, Implikasi Politik - Islam

Sejak masa Rasulullah SAW, terdapat kebijakan bagi kaum non-Muslim yang tetap dapat tinggal dalam pemerintahan Muslim dengan membayar semacam pajak atau Jizya.Hak-hak mereka dijamin dan dilindungi serta kewajiban mereka dalam urusan kemasyarakatan juga sama. Mereka disebut sebagai Dhimmi. Awalnya, Dhimmi ini merupakan kaum musyrik yang semula memerangi kaum muslimin dan berhasil dikalahkan sehingga Rasulullah menetapkan kebijaksanaan yang demikian. Kebijksanaan itu tetap diikuti dan dipegang teguh oleh para khalifah Rasulullah yang berkuasa selanjutnya.Termasuk oleh kekhalifahan Turki Utsmani.Wilayah Balkan yang mayoritas penduduknya beragama Nasrani pun mampu bertahan selama kurang lebih lima abad di bawah pemerintahan Turki Utsmani dengan kebijakan yang sama.

Semenanjung Balkan ini sebenarnya telah berhasil ditaklukkan oleh kaum muslim, tidak jauh selang waktunya dengan penaklukkan Konstantinopel. Serbia masuk dalam kekuasaan Turki Utsmani pada tahun 1459, Bosnia serta Herzegovina direbut pada tahun 1465 M, dan Yunani, termasuk Morea dan Euboea, jatuh ke tangan Utsmaniyah pada tahun 1468. Namun, seiring dengan kejayaan yang dicapai oleh kaum muslimin 
lewat ekspansi ini, di sisi lain bangsa Eropa sedang mencoba untuk bangkit dari tidurnya. Abad kegelapan atau yang lebih sering mereka sebut sebagai The Dark Ages, perlahan sirna seiring dengan Revolusi Perancis yang berlangsung antara tahun 1789-1815 yang melahirkan gagasan tentang hak-hak rakyat dan nasionalisme. Gagasan tersebut turut mempengaruhi berbagai bangsa yang berada di bawah naungan kekuasaan Turki Utsmani serta menimbulkan kekacauan (Lenczowski, 1993).

Pemberontakan-pemberontakan mulai digencarkan oleh para warga Kristen yang berada di bawah naungan kekuasaan Utsmani, khususnya di Balkan.Sejak perjuangan kemerdekaan Serbia pada tahun 1804-1813 M, satu per satu negara-negara Balkan melepaskan diri mulai dari Yunani (1832), Rumania (1856-1878), Montenegro (1878), dan Bulgaria (1878-1908), semuanya menyatakan diri sebagai negara-negara merdeka (Lenczowski, 1993). Dugaan mengenai sebab terjadinya pemberontakan untuk membebaskan Pada akhir tahun 1876 terjadi pemberontakkan di Serbia dan Bulgaria, akan tetapi tentara Turki mengatasinya dengan penindakan keras yang disebut "horor di Bulgaria" oleh pers Barat. Hal inilah yang menambah kebencian publik Eropa terhadap pemerintahan Utsmani.Dibumbui oleh propaganda Rusia yang bertujuan untuk melumpuhkan Turki Utsmani di mana Rusia memberi harapan menyelamatkan gerejagereja kepada Yunani, guna memetik keuntungan bagi Rusia sendiri yang ingin mempengaruhi rakyat non-muslim (Slav dan Yunani) untuk berontak terhadap Turki. Dapat dikatakan bahwa saat keadaan Kerajaan Usmani yang sudah kritis, Rusia membedah bagian-bagian tubuh sang sick man of Europe tersebut untuk dirinya dan bagi negara-negara di Eropa (Djaja, 2015).

Pemicu Perang Balkan itu sendiri ialah keinginan negeri-negeri Balkan seperti Bulgaria untuk membebaskan Macedonia yang saat itu masih berada di bawah kekuasaan Kekhalifahan Utsmaniyah. Sebenarnya, ada maksud lain dari Perang Balkan ini sendiri, bahwa selain untuk merebut Macedonia dari tangan Turki, para aliansi negara-negara Balkan yang terdiri dari Bulgaria, Serbia, Yunani dan Montenegro ini memiliki kepentingan-kepentingan dan ambisi masing-masing. Meski tujuan mereka pada umumnya sama, yakni ingin mengambil alih wilayah Eropa, khususnya wilayah Balkan yang masih berada di tangan Turki Utsmani. Mereka juga ingin mengusir selamanya Turki Utsmani dari Balkan (Karim, 2011).

Hal ini tidak terlepas dari dukungan dan dorongan dari Rusia terhadap negerinegeri Balkan tersebut, khususnya Serbia.Serbia kecewa karena Bosnia-Herzegovina diserahkan kepada Austria-Hungary pada tahun 1908 M tanpa persetujuan dari negerinegeri di Semenanjung Balkan. Rusia pun tidak puas dengan keputusan Austria-Hungary yang mencaplok Bosnia-Herzegovina sebagai wilayahnya, sebab Rusia khawatir kejayaan Austria-Hungary ini menjadi ancaman terhadap pengaruh Rusia di Balkan. Oleh karena itu, Rusia menganjurkan negeri-negeri Balkan untuk membentuk Liga Balkan (Aslizan, 2016) 
Terbentuknya Liga Balkan yang terdiri atas Yunani, Serbia, Bulgaria, dan Montenegro inilah yang memantikkan api peperangan antara negeri-negeri di Semenanjung Balkan dengan Kesultanan Turki Utsmani. Perlu diketahui bahwa, meskipun perang Balkan ini hanya berlangsung selama kurang lebih satu tahun, tetapi perang ini terjadi sebanyak 2 kali.Perang Balkan pertama yakni perang antara negerinegeri Balkan melawan Kesultanan Turki Utsmani dengan misi membebaskan Macedonia dan mengusir Turki Utsmani dari Balkan.

Adapun Perang Balkan kedua ialah perang antar sesama sekutu negara-negara Balkan itu sendiri dalam memperebutkan wilayah yang berhasil direbut dari tangan Turki Utsmani. Hal ini disebabkan tindakan Sir Edward Grey yang mendesak negeri-negeri Balkan tersebut untuk menandatangani perjanjian damai dengan Kesultanan Utsmaniyah tanpa adanya kesepakatan sebelumnya antara mereka mengenai pembagian wilayah yang berhasil direbut dari Turki Utsmani. Inilah yang menyebabkan negara-negara Balkan ini tidak puas dan kecewa satu sama lain yang akhirnya memicu genderang perang Balkan II. Sekali lagi, peperangan terjadi di Semenanjung Balkan (Grey, 2007).

Secara umum, Perang Balkan ini menimbulkan implikasi yang cukup signifikan terhadap kehidupan muslim di Eropa Tenggara, baik itu dari segi politik Islam maupun sosialnya. Setelah Perang Balkan berakhir, umat Islam mengalami kekalahan geo-politik yang belum pernah terjadi sebelumnya. Kekalahan geo-politik ini diiringi pula dengan kekalahan ekonomi yang berakhir dengan migrasi dan pembantaian populasi Muslim secara besar-besaran dari Balkan, menyisakan hanya sedikit populasi yang akan menjadi muslim minoritas dari negara nasional Balkan.

Berdasarkan pemaparan di atas, dapat dikatakan bahwa kajian mengenai Perang Balkan ini sangat menarik untuk dibahas. Intrik politik, dendam, ambisi, bahkan kecurigaan mereka satu sama lain sangat menimbulkan rasa keingintahuan penulis mengenai apa sebenarnya yang melatarbelakangi terjadinya Perang Balkan ini hingga di anggap sebagai Prelude (Permulaan) dari Perang Dunia I. Penulis juga ingin mengetahui lebih jauh tentang bagaimana kronologi perang Balkan tersebut, baik itu perang Balkan I atau pun perang Balkan II, serta bagaimana implikasinya terhadap kehidupan umat Islam di Balkan atau yang kini lebih sering disebut Eropa Tenggara. Sebab, selama beberapa abad umat Islam pernah menguasai negeri-negeri di Semenanjung Balkan. Pastilah, sedikit banyak, ada komunitas atau masyarakat muslim yang hidup di Balkan baik itu para imigran maupun penduduk asli dari negeri Balkan yang telah memeluk Islam.

Selain itu, mengingat masih sedikitnya bahasan mengenai Perang Balkan dan kehidupan umat Islam di Balkan itu sendiri, semakin memicu semangat penulis untuk meneliti lebih lanjut mengenai Perang Balkan ini.Berdasarkan alasan-alasan yang tersebut di atas, akhirnya mendorong penulis untuk mengangkatnya menjadi sebuah topik penelitian untuk kepentingan skripsi, dengan judul "Perang Balkan dan Implikasinya terhadap Kehidupan Sosial-Politik Islam di Eropa Tenggara (1876-1914 M)”. 


\section{Implikasi Perang Balkan terhadap Kehidupan Sosial-Politik Islam di Eropa Tenggara}

Setelah ekspedisi militer pertama ke wilayah Balkan pada tahun 1354, kehadiran Turki Utsmani di Balkan berlangsung selama lebih dari lima ratus tahun (Furrat, 2012). Berbicara mengenai populasi muslim Balkan atau Islam di Balkan, penting untuk mengenali betapa beragamnya populasi muslim ini. Masyarakat muslim Balkan secara keseluruhan berasal dari proses Islamisasi yang disertai oleh kedatangan Turki Utsmani di wilayah tersebut dari abad ke-14 hingga awal abad ke-20, tetapi masyarakat muslim Balkan ini sama sekali tidak dapat dideskripsikan sebagai masyarakat yang homogen. Mengingat pada bab terdahulu telah dipaparkan mengenai etnik Balkan yang amatlah heterogen (Bougarel, 2005).

Konflik yang terjadi di Balkan pada tahun 1912-1913 merupakan hasil daripada gejala diferensiasi sosial yang terjadi di Balkan. Selama Turki Utsmani berkuasa, diferensiasi sosial tersebut berlangsung terus menerus. Seperti penggolongan antara masyarakat Muslim dan Kristen yang diperlakukan berbeda, penduduk di perkotaan diperlakukan dengan cara yang berbeda dari warga pedesaan, dan sebagainya. Hal inilah yang menjadi bunga api pertama dari konflik yang berkepanjangan dan akhirnya menyebabkan terjadinya perang.

Sebagai konflik pertama yang melibatkan negara-negara Eropa pada abad ke-20, Perang Balkan memperkenalkan peperangan zaman modern yang melibatkan banyak tentara, mesin, termasuk populasi penduduk. Perang ini berhasil menyingkirkan Turki Utsmani dari Eropa, kecuali bagian Thrace Timur. Seorang pemimpin Muslim India menilai perselisihan Balkan tersebut sebagai berikut:

"Raja Yunani telah memaklumkan perang salib baru. Dari dewan-dewan di London dikeluarkanlah seruan, bagi fanatisme Kristen, dan Santo Petersburg telah memerintahkan penempatan salib di atas Santo Sophia. Hari ini mereka berkata demikian, besok mereka akan memerintahkan yang serupa mengenai Yerusalem dan Masjid Umar. Saudara-saudara! Insyaflah, bahwa kewajiban mereka yang sungguh-sungguh beriman ialah berkumpul di bawah bendera Khalifah dan mengorbankan hidupnya demi keselamatan keyakinan kita."

Mengacu kepada teori konflik yang telah dipaparkan pada bab yang terdahulu, dinyatakan bahwa konflik tidak selalu berimplikasi negatif, dalam artian konflik menjadi penyebab perusak integrasi dan kesatuan masyarakat. Hal ini menunjukkan bahwa di pihak lain ternyata konflik berimplikasi pada hal positif dan sebagai sumber perubahan. Berdirinya Albania sebagai negara independen merupakan contoh implikasi dari konflik yang positif. Sebagai hasil dari Perjanjian London, Albania berhasil menjadi negara yang independen 


\section{Dampak Perang Balkan terhadap Kehidupan Politik Islam di Eropa Tenggara}

Berbicara mengenai kekuasaan Islam di Eropa Tenggara, ini berarti akan membahas bagaimana dampak yang ditimbulkan dari Perang Balkan atas keberlangsungan kekuasaan Turki Utsmani serta Muslim khususnya pasca Perang Balkan. Secara politis, pada perang Balkan pertama, Turki Utsmani telah kehilangan seluruh wilayah kekuasaannya di Eropa. Jelas, kaum muslim yang selama ini menikmati status istimewa di bawah pemerintahan Turki Utsmani harus menerima kenyataan bahwa mereka tidak akan lagi mendapat perlakuan yang sama. Kekalahan telak yang dialami Turki Utsmani terhadap keempat anggota Liga Balkan menyebabkan dampak yang luar biasa bagi Kesultanan Turki Utsmani dan masyarakat Balkan itu sendiri (Setiadi, 2013) .

Selain itu, perang Balkan juga menyebabkan isolasi diplomatik kerajaan Utsmani, dan pihak Unionis merasa yakin bahwa isolasi berkelanjutan berarti berakhirnya Kesultanan Utsmani. Karena ingin menghindari isolasi politik yang diduga akan berakhir buruk inilah akhirnya Turki Utsmani ikut melibatkan diri ke dalam Perang Dunia pada tahun 1914. Dalam suasana ketegangan internasional yang memuncak, pemerintahan Unionis di Kerajaan Utsmani berusaha untuk membentuk aliansi. Pada dasarnya, pemerintahan Utsmani saat itu siap untuk menerima aliansi manapun daripada mengalami isolasi lebih jauh. Namun, di pihak lain wilayah Albania yang penduduknya merupakan mayoritas muslim berhasil memperoleh kemerdekaannya. Untuk lebih jelasnya mengenai dampak politis yang ditimbulkan dari Perang Balkan akan dipaparkan sebagai berikut (Thohir, 2013).

\section{Perselisihan Batas Wilayah}

Albania menyatakan kemerdekaannnya dari Imperium Utsmani pada November 1912 dengan 70\% penduduknya adalah Muslim. Begitu pernyataan ini dilaksanakan, kekuatan-kekuatan Kristen tetangganya mulai menyerbu seluruh provinsi-provinsi Albania dan menggabungkannya ke dalam wilayah mereka sendiri. Serbia mendapatkan Kosovo dan Macedonia Barat, Montenegro menundukkan daerah-daerah tetangganya, dan Yunani mengambil alih Khamiria, termasuk kota terkenal Janina.

Akibatnya, daerah asli Albania berkurang dari sekitar 70.000 kilometer persegi menjadi hanya 28.748 kilometer persegi. Suatu konferensi di London diadakan para duta besar Eropa untuk bertemu dan memastikan batas-batas negara baru kepada para penakluk tanah-tanah Albania. Lebih buruk lagi, Muslim tidak diperbolehkan untuk memimpin di Albania melainkan non-Muslim. Negara-negara besar Eropa memilih orang Kristen asing yakni Pangeran Jerman, Wilhelm zu Weid, untuk menjadi raja Albania. Kuasa-kuasa agung sendiri yang memilih Wied, seorang tentara Jerman dan keponakan dari Ratu Elisabeth Rumania. Dia menggantikan pemerintah sementara yang didirikan oleh Ismail Kemal pada November 1912 
Namun, Pangeran Wilhem ini menetap di Albania hanya beberapa bulan. Ketika Perang Dunia I meletus 6 bulan kemudian pangeran Wilhelm meninggalkan Albania. Selanjutnya Albania mengalami keadaan anarki selama suatu periode sekitar sepuluh tahun sampai Ahmad Beg Zogu menyatakan Negara itu menjadi republik dengan dia sendiri sebagai presiden pertamanya.

\section{Perebutan Kekuasaan Antar Negara Balkan}

Sebagai dampak langsung dari Perang Balkan I, merdekanya Albania berhasil membatasi Serbia dan mencegahnya menjadi kekuatan maritim baru di Adriatik. Ini dikarenakan desakan Austria, yang tujuan utama politiknya ialah mencegah Serbia untuk tidak memperoleh jalur keluar ke laut Adriatik. Hal ini dilakukan Austria karena kekuatan Serbia yang ditakutkan akan menyainginya sebagai kekuatan baru di Eropa. Tentu saja, hal tersebut sangat tidak diinginkan oleh Austria.

Negara Eropa memaksa Serbia dan Montenegro untuk menarik diri dari wilayah Albania yang mereka taklukkan dalam Perang Balkan I. Pemerintah Serbia yang frustasi oleh hilangnya wilayah Albania, mencari kepuasan di wilayah Makedonia yang dikuasai Bulgaria dan Yunani. Bangsa Bulgaria, yang meyakini mereka berperan penting dalam pertempuran melawan Turki, menolak menyerahkan wilayah apapun kepada Serbia dan menolak upaya Rusia sebagai mediator. Pada tanggal 29-30 Juni 1913, pasukan Bulgaria menyerang wilayah Serbia dan Yunani di Makedonia, yang memicu perang Balkan II.

Perjanjian London yang awalnya bertujuan untuk menghentikan Perang Balkan I dengan damai, berujung menjadi pencetus meletusnya Perang Balkan II karena perebutan kekuasaan yang tidak terselesaikan. Hal ini menunjukkan bahwa dengan adanya ketidakpuasan atas resolusi yang dilakukan untuk menyelesaikan perang, malah dapat menimbulkan terjadinya perang lagi.

\section{Hancurnya Kesatuan Wilayah Turki Utsmani}

Hancurnya kesatuan wilayah Turki Utsmani menyebabkan terpolarisasinya politik di Istanbul. Kehilangan Libya tidak ada artinya dibandingkan dengan menyerahkan Albania, Makedonia, dan Thrace. Sejak direbut dari Kekaisaran Bizantium lima abad sebelumnya, wilayah-wilayah Eropa telah menjadi jantung ekonomi dan administrasi dunia Utsmani. Ketiga wilayah tersebut juga merupakan provinsi yang paling makmur dan berkembang di seluruh Kerajaan. Selain itu, Macedonia, Thrace dan Albania merupakan provinsiprovinsi terkaya dan termaju serta sebagian dari kaum elite Utsmani yang berkuasa berasal dari sana (Rogan, 2016)

Hilangnya pendapatan diperparah oleh tingginya biaya Perang Balkan I atas kas Utsmaniyah. Ribuan pengungsi memerlukan upaya pemukiman kembali. Selain itu, kelaparan pada gilirannya membuat penduduk rentan terhadap wabah penyakit, yang biasanya menyerang penduduk yang lemah karena kekurangan makanan. Pemerintah juga menghadapi pengeluaran yang luar biasa besar untuk membangun kembali angkatan 
bersenjata Utsmani setelah kerugian korban jiwa dan harta yang disebabkan dua perang yang gagal (Perang Turki-Itali dan Perang Balkan I). Pembangunan pemukiman kembali untuk mereka menimbulkan masalah-masalah besar dan banyak pengungsi yang menghabiskan beberapa tahun berikutnya sebagai penghuni liar di kota-kota.

Kerajaan hampir kehilangan seluruh wilayahnya di belahan Eropa, keseluruhannya sekitar 60.000 mil persegi, dengan penduduk sekitar 4 juta orang. Lagi pula, seperti pada tahun 1878, Istanbul dipenuhi oleh para pengungsi muslim yang telah kehilangan segalanya. Di sana wabah tifus dan kolera melanda dan terdapat tingkat kematian tinggi di kalangan para pengungsi tersebut. Selain Thrace Timur, seluruh wilayah Turki Utsmani di Eropa hilang (Zurcher, 2003).

Dampak dominan yakni dampak moral publik. Kekalahan atas salah satu negara Eropa yang relatif maju seperti Italia memang buruk, tetapi baik pasukan maupun masyarakat umum Utsmani tidak bisa menerima kekalahan di tangan negara-negara Balkan kecil yang dulunya bagian dari Khilafah mereka. Yusuf Akcura, seorang intelektual Turki muda menulis:

"Bangsa Bulgar, Serbia, Yunani jajahan kita selama lima abad, yang kita benci, telah mengalahkan kita. Kenyataan ini, yang bahkan tidak bisa kita bayangkan dalam imajinasi kita, akan membuka mata kita ... jika kita belum sepenuhnya mati" (Rogan, 2016).

Hal ini menunjukkan bahwa awalnya Kesultanan Turki Utsmani meremehkan kekuatan bangsa Balkan yang dulunya mereka jajah. Namun, bangsa Balkan yang mereka remehkan itu malah mampu mengalahkan mereka sehingga sulit bagi mereka untuk menerima kenyataan bahwa mereka telah kalah dan kehilangan banyak wilayah.

\section{Dampak Perang Balkan Terhadap Kehidupan Sosial Masyarakat Muslim di Eropa Tenggara}

Peperangan yang terjadi di Balkan selama tahun 1912-1913 M ini menimbulkan malapetaka kemanusiaan yang luar biasa. Pada perang Balkan pertama Bulgaria kehilangan 14.000 jiwa, 50.000 terluka, dan 19.000 tewas akibat penyakit. Dalam Perang Balkan kedua Bulgaria menderita 18.000 korban jiwa, 60.000 terluka dan 15.000 tewas akibat penyakit. Kerugian yang tinggi bagi Bulgaria dalam Perang Balkan II terjadi selama pertempuran yang intens dengan Yunani dan Serbia hanya dalam waktu yang singkat (Hall, 2000).Berbeda halnya dengan Yunani yang hanya mengalami kerugian korban jiwa sebanyak 5.169 orang, dan 23.502 terluka pada perang Balkan I. Sedangkan dalam Perang Balkan II hanya sekitar 2.563 korban jiwa dan 19.307 yang terluka. Sementara pada Perang Balkan I Montenegro mengalami kerugian korban 2.836 jiwa, dan 6.602 terluka. Sebagian besar kerugian ini dihasilkan dari operasi militer di sekitar Scutari. Montenegro juga kehilangan 240 jiwa dan 961 terluka dalam Perang Balkan II. Kerugian yang dialami ini merupakan angka yang tinggi untuk sebuah negara yang kecil seperti Montenegro. 
Pemenang terbesar dalam Perang Balkan ialah Serbia. Bukan hanya tentara Serbia berhasil memenangkan pertempuran atas pasukan Turki Utsmani di Albania, Macedonia, Thrace dan atas tentara Bulgaria di Macedonia, tetapi Serbia dengan hebatnya mengekspansi wilayah dan penduduknya. Tentunya ekspansi ini berakhir dengan kekejaman terhadap populasi Muslim.

Serbia yang merupakan pemenang utama dalam Perang Balkan yang diperkirakan hanya mengalami kerugian sekitar 36.550 korban jiwa dan 55.000 orang terluka. Jumlah lain mengindikasikan kerugian Serbia dalam perang dengan Bulgaria sekitar 9.000 tewas di medan perang, 5.000 orang tewas akibat penyakit kolera dan 36.000 terluka (Hall, 2000).

Sementara, kerugian jiwa yang dialami oleh Turki Utsmani sulit untuk dipastikan. Hal ini dikarenakan pasukan Turki Utsmani sering mundur atau melarikan diri dari medan pertempuran, sehingga Turki Utsmani tidak selalu mampu untuk menghasilkan perkiraan mengenai jumlah tewas dan terluka. Selama perang Balkan I, total korban jiwa dari pihak Turki Utsmani kemungkinan berjumlah sekitar 100.000 orang. Sumber lain menyebutkan bahwa diperkirakan 125.000 tentara Turki Utsmani terbunuh dalam perang atau mati karena penyakit dan mati kelaparan. Kebanyakan kematian ini merupakan hasil langsung dari perang misalnya, para tawanan perang Turki yang dibunuh oleh Bulgaria di Stara Zagora yang berjumlah sekitar 500 hingga 600 orang (Hall, 2000).

Tingginya korban jiwa ini menyebabkan berkurangnya populasi dari Turki Utsmani dan mempercepat proses terjadinya disintegrasi. Selain itu, Perang Balkan juga menghapus generasi bangsa Bulgaria, Yunani, Montenegro dan Serbia dengan jumlah yang tidak sedikit. Khususnya bagi Bulgaria, yang menderita kerugian korban jiwa dengan jumlah yang tinggi dalam kedua Perang Balkan tersebut. Adapun situasi dan kondisi yang dialami masyarakat Muslim di Eropa Tenggara pasca Perang Balkan akan penulis paparkan sebagai berikut.

\section{Hancurnya Nilai-Nilai dan Norma}

Sementara Serbia dan Montenegro menerima penduduk Albania, orang-orang Yunani mengikuti kebijakan pengusiran orang-orang Muslim Albania dari wilayah yang mereka taklukkan. Memang sebelum terjadinya Perang Balkan, penganiayaan dan perlakuan buruk terhadap muslim sudah berlangsung, akan tetapi keadaan itu semakin buruk ketika otoritas muslim yakni Turki Utsmani mengalami kekalahan telak pada perang Balkan I. Misalnya, pada tahun 1876, Muslim merupakan mayoritas di banyak kota utama, seperti Varna, Plovdiv (filipe), Pleven, dan sebagainya. Muslim juga menjadi minoritas yang penting di Kota Sofia. Setelah perang Krimea, Negara Utsmani menempatkan para pengungsi Muslim dari Krimea di daerah itu, atau sekitar 350.000 orang, diantara 100.000 orang tersebut adalah orang Tartar dan 90.000 orang Circassia. Namun, perang antara Turki dan Rusia pada tahun 1877 merupakan malapetaka bagi 
penduduk Muslim dan menyebabkan terjadinya dislokasi besar dan emigrasi masa ke Anatolia (McCarthy, 2017).

Penganiayaan komunitas Muslim meningkat intensitasnya setelah kemerdekaan Bulgaria pada tahun 1908 yang menyebabkan terjadinya gelombang emigran baru menuju Turki. Kenyataannnya, pemerintah kerajaan Bulgaria tetap mengikuti kebijakan melenyapkan penduduk Muslim dengan semangat yang tercemar oleh fanatisme keagamaan. Hal ini menyebabkan berkurangnya penduduk Muslim di Bulgaria dari sekitar 50\% pada tahun 1876 menjadi hanya 13\% pada 1939 dengan hanya 858.000 Muslim di antara penduduk yang berjumlah 6.600.000 orang (McCarthy, 2017).

Apalagi pada Oktober 1912 Yunani, Bulgaria, Serbia, dan Montenegro sepakat untuk menyerang Turki Utsmani dan mengusirnya dari Balkan. Permasalahannya ialah penduduk mereka merupakan minoritas di Ottoman Eropa. 51\% penduduk mereka adalah Muslim, terutama Albania di Barat, dan Turki di Timur. Mereka menyadari bahwa mayoritas muslim akan selalu menjadi ancaman terhadap kekuasaan mereka. Solusinya ialah dengan pengusiran dan pembunuhan kaum muslim (McCarthy, 2017).

Tidak diragukan lagi penduduk Albania di Kosovo dan Albania Utara mengalami penderitaan yang memilukan di tangan tentara-tentara Montenegro dan Serbia. Fritz Magnussen, seorang koresponden untuk Koran DanishRiget, menulis:

Aktivitas militer Serbia di Macedonia telah mengambil sikap pemusnahan populasi Arnaut (Albania). Para tentara melaksanakan sebuah kekejaman perang yang amat buruk. Berdasarkan para pegawai dan tentara, sejumlah 3.000 orang Arnaut dibantai di wilayah antara Kumanova/Kumanovo dan Skopje dan sejumlah 5.000 orang di dekat Prishtina. Kampung Arnaut dibakar, dan para penduduknya diusir dari rumah mereka dan ditembak seperti tikus. Tentara Serbia dengan gembira memberitahu saya mengenai perburuan manusia yang mereka lakukan (Hall, 2000)

Selain Fritz Magnussen, sumber lain juga menyebutkan kekejaman perang yang dilakukan terhadap umat Muslim melalui tulisan seorang Konsulat Inggris, yakni Lamb yang menulis:

"Melewati daerah Kilkish, Doiran, dan Ghevgheli hampir semua pemimpin Muslim telah dibunuh, harta benda mereka dirampas atau pun dirusak, peternakan dan rumah kediaman mereka dibakar. Perempuan-perempuan mereka dilecehkan, dan seringkali lebih buruk" (McCarthy, 2017).

Pada setiap wilayah, penduduk desa dirampok mulai dari binatang ternak hingga bibit pertanian di mana hidup mereka bergantung. Mereka tidak memiliki makanan, dan tidak ada satupun negara pemenang yang menyediakan makanan bagi mereka sehingga mereka kelaparan. Pengamat Eropa melaporkan kasus-kasus pembunuhan, perusakan, dan kelaparan dari seluruh bekas wilayah Turki di Eropa. 
Penduduk Muslim yang melarikan diri ke wilayah Serres mencapai seribu orang. Saat pertempuran berakhir, otoritas yang baru memberitahu penduduk Muslim bahwa mereka akan aman jika kembali ke desa mereka. Ketika tiba, mereka menemukan bahwa desa mereka telah dihancurkan lalu mereka dikumpulkan di kota-kota seperti Petrich, dimana 200 orang dibunuh oleh pasukan Bulgaria, 120 orang dibantai di Orman Ciftlik, lebih jauh 150 orang di Gjurgjevo. Sementara, 364 orang yang bertahan hidup di Petrich diperintah untuk berkumpul di barak kota, akantetapi pada akhirnya 260 orang dari mereka dibunuh disana dengan bayonet. Mengenai apa yang terjadi dengan 100 orang yang bertahan tidak diketahui secara pasti, mereka barangkali ikut pergi ke wilayah Turki yang tersisa (McCarthy, 2017).

Di akhir peperangan, orang-orang yang berhasil bertahan dan tidak mampu melarikan diri dari Eropa, melarikan diri ke Thrace Timur dan Anatolia, serta mengambil apa yang tersisa dari milik mereka. Tanah, rumah, bisnis bahkan peternakan mereka hilang, dan tentunya tidak ada kompensasi atas itu semua. Tidak ada yang menghitung jumlah besar kematian di Albania. Hal ini dikarenakan tidak adanya sensus di Albania setelah perang untuk membandingkan jumlah yang bertahan dari sebelum perang. Diluar Albania, 2.3 juta muslim tinggal di wilayah taklukkan Utsmani sebelum perang. Pada tahun 1926, hanya 870.000 orang yang masih tinggal di kampung halaman mereka.

Sementara itu, Penduduk muslim yang secara etnik beragam di Macedonia meninggal dan menjadi pengungsi seperti rekan Kristen mereka, terutama sebagai akibat dari perang Balkan 1912-1913. Hal ini menunjukkan bahwa dengan adanya perubahan situasi politis yakni perpindahan kekuasaan dari Muslim ke non-Muslim jumlah umat Muslim di Balkan semakin berkurang.

\section{Diskriminasi Kelompok}

Haruslah diingat bahwa sejak disintegrasi dari kerajaan Turki Utsmani, populasi muslim Balkan dalam posisi politis merupakan suatu minoritas. Sejak itu, mayoritas politis yang baru di negara Balkan melakukan diskriminasi dan penindasan terhadap mereka. Karena situasi ini, antara tahun 1878-1945, dua hingga tiga juta muslim berimigrasi ke Turki (Iseni, 2009).

Setelah disintegrasi dari Kesultanan Turki Utsmani, otoritas keagamaan Muslim di Balkan ditempatkan secara langsung di bawah pemerintahan negara baru Balkan. Oleh karena itu, mereka harus lebih dulu menyesuaikan diri terhadap status minoritas baru mereka, di luar dari moderenisasi masyarakat dan negara) (Iseni, 2009).

Kecepatan sekutu dalam memenangkan pertempuran semakin menambah penderitaan orang-orang Turki dan orang-orang Albania. Para Muslim yang tinggal di desa mereka untuk menunggu hasil dari pertempuran, akan tetapi setelah kekalahan Utsmani, desa-desa diserang oleh gerombolan gerilya dan Muslim pun berusaha menyelamatkan diri. Namun, mereka diserang lagi ketika dalam perjalanan, beberapa 
mungkin berhasil mencapai pelabuhan-pelabuhan seperti Salonika atau Kavalla untuk menaiki kapal ke pelabuhan Anatolia.

Saat pasukan negeri pemenang mengambil alih pelabuhan, bahaya bagi para pengungsi Muslim semakin mengintai. Barangkali, para pengungsi berhasil selamat dari serangan palsu di Salonika, akan tetapi tidak selamat dari bahaya kelaparan dan penyakit selama mereka menunggu transportasi dari kampung halaman mereka. Sekitar 30.000 pengungsi menunggu disana pada bulan Maret 1913.

Kebanyakan muslim tidak dapat melarikan diri atau setidaknya mereka tidak berhasil melarikan diri. Para tentara memblokade jalan, sehingga tidak memungkinkan bagi mereka untuk berpergian melalui jalur darat menuju Istanbul sementara Turki Utsmani dan Bulgaria sedang bertempur di Catalca. Mereka seringkali tidak berhasil mencapai pelabuhan. Konsulat Lamb melaporkan:

"Dari sekitar 1500 Muslim yang mencoba untuk melarikan diri ke Cavalla (dari Drama) sekitar setengah dari mereka yang yakin untuk mencapai Cavalla. Selama 8 atau 10 hari sesudahnya, jalan-jalan dinyatakan telah bertaburan mayat yang belum dikubur." Banyak peraturan di jalan hanya untuk memaksa mereka kembali diserang seperti halnya tentara, bahkan pasukan gerilya memblokade jalan lintasan mereka (McCarthy, 2017).

Selain mereka yang mencoba untuk melarikan diri, banyak juga penduduk desa yang tidak pernah pergi dikarenakan takut dalam perjalanan atau memang tidak ingin meninggalkan rumah-rumah mereka. Padahal setelah peperangan berakhir, tidak terdapat keamanan di banyak desa. Seorang Konsulat Inggris, Grieg di Manastir menulis:

"Perang telah menyebabkan penderitaan di wilayah Manastir. Saat melewati wilayah Manastir, Kirchevo, Florina, Serfidjé, Hailar, Kozhani, Elassona, Grevena, Naselitch, dan Kastoria, sekitar $80 \%$ penduduknya adalah Muslim, dan dari seperempat penduduk muslim dengan populasi campuran telah dijarah bahkan sebagian atau seluruh desa dirusak. Keadaan yang sama juga dialami oleh kaum Kristen dan Muslim di wilayah Gorcha dan Dibra. Selanjutnya, terdapat persaingan antara tentara dan para perampok dari daerah tetangga Kristen yang merupakan penanggung jawab utama dalam perusakan desa-desa tadi” (McCarthy, 2017).

Situasi yang sama dialami di setiap wilayah. Konsulat melaporkan bahwa Bulgaria telah merusak seluruh desa muslim di wilayah yang mereka duduki di Thrace. Sementara, Serbia menghancurkan kampung muslim di Macedonia utara dan Albania. Montenegro bertaruh habis-habisan ke Albania Utara, dan hanya menyisakan sedikit tempat bagi Muslim. Sekalipun begitu hebatnya kekejaman dan pengusiran terhadap Muslim, tetapi masih ada Muslim Balkan yang mampu bertahan. 


\section{Pebi Sapitri}

Perang Balkan dan Implikasinya terhadap Kehidupan Sosial-Politik di Eropa Tenggara (1876-1914 M)

\section{Bertambahnya Solidaritas Internal}

Albania, merupakan salah satu negeri Balkan yang menjadi korban dari kekejaman di mana penduduknya tidak memiliki tempat untuk melarikan diri selama perang. Meski jumlah penduduk Albania yang meninggal ataupun terluka selama Perang Balkan sulit ditentukan, akan tetapi banyak orang Albania yang ikut bertempur sebagai anggota tentara atau berpihak kepada tentara Turki Utsmani, sedangkan yang lainnya melawan invansi Yunani, Montenegro, dan Serbia atas wilayah mereka secara terpisah. Invansiinvansi ini menyebabkan jumlah korban jiwa yang tak terhitung dan kerusakan di banyak tempat. Tidak diragukan lagi, bagian utara dan selatan, wilayah yang paling sering bertempur dan daerah yang didambakan oleh para penyerbu, menderita kerugian demografis yang besar (Hall, 2000).

Hal ini menunjukkan implikasi positif yang timbul akibat pecahnya Perang Balkan. Semakin meningkatnya rasa solidaritas Albania sebagai sesama Muslim kepada Turki Utsmani terbukti dengan banyaknya Muslim Albania yang turut membantu para tentara Turki Utsmani dalam melawan para aliansi Liga Balkan. Meskipun pada akhirnya Muslim Albania mengalami banyak kerugian baik itu harta, jiwa, bahkan wilayah territorial mereka. Walaupun Albania memang menginginkan kemerdekaan dan memisahkan diri dari Turki Utsmani, Albania tidak melupakan identitas mereka sebagai sesama Muslim yang harus saling membantu.

Komunitas Muslim yang hidup di Eropa Tenggara setelah Perang Balkan dapat dibagi dalam dua kategori yakni pertama komunitas-komunitas yang bertahan hidup atas kekalahan Turki Utsmani, dan komunitas-komunitas yang beremigrasi karena kolonisasi Eropa di negeri-negeri Muslim. Walaupun jumlah penduduk Muslim yang tewas ataupun melarikan diri tidak terhitung akibat dari kekejaman Perang Balkan, bukan berarti populasi Muslim di Balkan menghilang, akan tetapi populasi Muslim ini dihadapkan kepada situasi yang sulit di mana mereka harus bertahan di tanah air mereka dengan keyakinan Islam di mana otoritas telah beralih ke non-Muslim.

\section{Kesimpulan}

Berdasarkan pembahasan pada bab-bab yang terdahulu, dapat disimpulkan bahwa, Perang Balkan merupakan perang antara negara-negara Balkan dengan Kesultanan Turki Utsmani di wilayah Balkan yang berlangsung dari tahun 1912 hingga tahun 1913. Pada dasarnya, penyebab utama terjadinya Perang Balkan ini ialah karena ambisi dan dendam pribadi antara masing-masing penguasa negeri Balkan dengan Kesultanan Turki Utsmani. Didorong pula oleh kemunduran Kesultanan Utsmani, dominasi Rusia, perang Turki-Itali (1911-1912), ide nasionalisme, propaganda, terbentuknya aliansi Balkan serta gagalnya diplomasi.

Secara kronologis, Perang Balkan pertama dimulai pada tanggal 8 oktober 1912 M, terhitung dua lawan satu, Turki Utsmani dengan cepat dikalahkan oleh keempat 
anggota Liga Balkan. Hanya tiga benteng pertahanan kota yang mampu dipertahankan cukup lama yakni Yanya (Ioannina), Uskudar (Shkoder), dan Edirne. Namun, kesemuanya ini jatuh pada April 1913 M. Selain Istanbul, pada akhir Perang Balkan I seluruh wilayah Turki Utsmani di Eropa hilang yang ditandai dengan perjanjian London pada 30 Mei 1913. Selanjutnya, pada 1 Juni 1913 para negara anggota Liga Balkan bersiteru antara mereka sendiri untuk memperebutkan wilayah taklukkan yang berhasil direbut dari Kesultanan Turki Utsmani sehingga meletuslah Perang Balkan II. Turki Utsmani mengambil keuntungan dari konflik para bangsa Balkan untuk mengambil kembali Edirne dan Thrace timur (saat ini Turki Eropa).

Implikasi yang ditimbulkan dari Perang Balkan terhadap kehidupan Muslim di Balkan atau kini lebih sering disebut Eropa Tenggara bukan hanya menimbulkan implikasi negatif, akan tetapi juga positif. Secara politis, terdapat tiga dampak yang timbul yakni: a. Perselisihan batas wilayah, b. Perebutan kekuasaan antar anggota Liga Balkan, c. Hancurnya kesatuan wilayah. Selain itu, dari segi sosial masyarakat Muslim Balkan terdapat tiga implikasi yang muncul yakni: a. Hancurnya nilai-nilai dan norma, $b$. Diskriminasi kelompok, dan c. Bertambahnya solidaritas internal, yang merupakan salah satu implikasi positif yang timbul akibat Perang Balkan. Secara umum, muslim Balkan menjadi minoritas di kalangan mayoritas Kristen Balkan.

Akibat dari kekejaman perang, banyak populasi muslim yang melarikan diri ke Anatolia sehingga populasi Muslim di Balkan pada waktu itu berkurang secara signifikan. Pembantaian muslim, perusakan kampung muslim, dan kekejaman lainnya telah berlangsung selama dan setelah Perang Balkan. Populasi muslim yang mampu bertahan hidup di Balkan harus menyesuaikan diri dengan pemerintahan baru yang telah dipegang oleh kaum Kristen. 
Pebi Sapitri

Perang Balkan dan Implikasinya terhadap Kehidupan Sosial-Politik

di Eropa Tenggara (1876-1914 M)

\section{DAFTAR PUSTAKA}

Bougarel, Xavier. 2017. "The Role of Balkan Muslims in Building a Eropean Islam". EPC Issue Paper No. 43, 23 November 2005. Diakses dari www.epc.eu pada 10 Januari 2017

C. Hall, Richard. 2000. The Balkan Wars 1912-1913: Prelude to the First World War. London: Routledge.

Djaja, Wahjudi. 2015. Sejarah Eropa: Dari Eropa Kuno Hingga Eropa Modern. Yogyakarta: Ombak.

Iseni, Bashkim. 2016. "National Identity, Islam and Politics in the Balkan" (Universite de Lausanne, 2009), h. 4 diakses dari http://downloads.akademiers.de/interneligioeser-dialog/091120_iseni_balkan.pdf pada 9 November 2016

Justin McCarthy. 2017. "1912-1913 Balkan Wars Death and Forced Exile of Ottoman Muslims: An Annotated Map", diakses dari www.tc-america.org pada 25 Maret 2017

Furat, Ayse Zisan dan Hamit Er. 2012. Balkans and Islam: Encounter, Transformation, Discontinuity, and Continuity. t.tp: Cambridge Scholar Publishing.

Lenczowski, George. 1993. Timur Tengah di Tengah Kancah Dunia, terj. Asgar Bixby. Bandung: Sinar Baru Algensindo.

M. Tahir Kasnawi dan Sulaiman Asang. "Konsep dan Pendekatan Perubahan Sosial".Diaksesdari http://www.pustaka.ut.ac.id/lib/wpcontent/uploads/pdfmk/IPEM4439-

M1.pdfpada 3 November 2016

Rogan, Eugene. 2016. The Fall of The Khilafah, terj. Fahmi Yamami. Jakarta: PT. Serambi Ilmu Semesta.

Setiadi, Elly M. dan Usman Kolip. 2013. Pengantar Sosiologi Politik. Jakarta: Kencana. Thohir, Ajid. 2011. Studi Kawasan Dunia Islam (Perspektif Etno-Linguistik dan GeoPolitik). Jakarta: Rajawali Pers. 